\title{
Can Native Parasitoids Control the Invasive Lime Leaf-Miner Phyllonorycter issikii (Lepidoptera: Gracillariidae) in Western Siberia? ${ }^{\dagger}$
}

\author{
Natalia Kirichenko 1,2, , Maria Ryazanova 2, Evgeny Akulov ${ }^{3}$, Margarita Ponomarenko 4,5
}

Citation: Kirichenko N., Ryazanova M., Akulov E., Ponomarenko M. Can native parasitoids control the invasive lime leaf-miner Phyllonorycter issikii (Lepidoptera: Gracillariidae) in Western Siberia?, in Proceedings of the 1st International Electronic Conference on Entomology, 1-15 July 2021, MDPI: Basel, Switzerland, doi:10.3390/IECE-10537

Published: 1 July 2021

Publisher's Note: MDPI stays neutral with regard to jurisdictional claims in published maps and institutional affiliations.



Copyright: (c) 2021 by the authors. Submitted for possible open access publication under the terms and conditions of the Creative Commons Attribution (CC BY) license (http://creativecommons.org/licenses /by/4.0/).
1 Sukachev Institute of Forest, Siberian Branch of the Russian Academy of Sciences, Federal Research Center «Krasnoyarsk Science Center SB RAS», Krasnoyarsk, Russia; nkirichenko@yahoo.com

2 Siberian Federal University, Krasnoyarsk, Russia; madam.rayzanova@yandex.ru

3 All-Russian Plant Quarantine Center, Krasnoyarsk branch, Krasnoyarsk, Russia; akulich80@yandex.ru

4 Federal Scientific Center of the East Asia Terrestrial Biodiversity FEB RAS, Vladivostok, Russia; margp@biosoil.ru

5 Far Eastern Federal University, Vladivostok, Russia

* Correspondence: nkirichenko@yahoo.com

† Presented at the 1st International Electronic Conference on Entomology (IECE 2021), 1-15 July 2021; Available online: https://iece.sciforum.net/.

The lime leafminer Phyllonorycter issikii (Kumata) (Lepidoptera: Gracillariidae) is an invasive micromoth from East Asia that nowadays is found in many regions across the Palearctic $[1,2]$. Known as a pest of limes (Tilia spp., Malvaceae), it is able to outbreak in both native and urban plantings in the invaded regions. For the first time, the moth was recorded in Russia in Moscow in 1985 [3]. In Siberia, in particularly in its western part, it was documented in 2006 [4]. Two years later, Ph. issikii was detected further east, in Novosibirsk Oblast [5], where it noticeably damages the native small-leaved lime (Tilia cordata). Presently, the moth is known from the majority of the regions in Western Siberia where the lime grows $[2,6]$.

In the end of June 2020, we documented numerous mines of Ph. issikii on lime trees in the Central Siberian botanical garden, Siberian Branch of the Russian Academy of Sciences (CSBG SB RAS, Novosibirsk). Despite the pest prefers to develop on shaded leaves in the lower part of tree crown [7], in the studied year in Novosibirsk the mines were found on the leaves across the whole tree crown, with the maximal density in its lower part. The mines were also detected on upper side of leaves and on bracts.

Here we aimed (1) to estimate relative number of mines per leaf; (2) to assess the survival of Ph. issikii on T. cordata, a plant with which the pest established a novel trophic association during its invasion westward, and (3) to define the infestation of the late instar larvae and pupae of Ph. issikii by the native parasitoid wasps (Hymenoptera: Eulophidae, Ichneumonidae, Braconidae).

We sampled by 300 leaves in the lower part of the crown from three lime trees of $T$. cordata in the arboretum of CSBG SB RAS on $25^{\text {th }}$ of June 2020. The leaves carrying mines (already with the late instar larvae and pupae) were placed by five per a Petri dish ( $90 \mathrm{~mm}$ in diameter) in 15 replications (i.e. 15 dishes involved). The number of mines was preliminarily counted on all leaves placed in the dishes. The dishes were kept in stable laboratory conditions $\left(+24^{\circ} \mathrm{C}, 65 \%\right.$ of humidity; $17 / 7 \mathrm{~h} \mathrm{light} /$ dark) and checked regularly to count the number of hatched moths and parasitoid adults. The number of mines was counted per a leaf; the number of emerged adult moths and emerged parasitoids were recalculated per a number of mines on the leaves. The remaining leaves were kept in six plastic containers (one-liter volume) for mass rearing and obtaining the representative set of parasitoids for further identification. The parasitoids were collected in the microtubes with $95 \%$ alcohol solution for further study. 
On average, $7,1 \pm 2,5$ mines per a leaf was documented on $T$. cordata in the arboretum of CSBG SB RAS. In one case, we counted 29 mines on a leaf (the mines were present on both sides of the leaf lamina), that was the maximal absolute number of mines on an average-size leaf. In the laboratory rearing, up to $70 \%$ of pupae successfully developed to adults. The remaining late instar larvae and pupae (i.e. 30\%) died, among which only $7.4 \%$ of the moth's individuals were parasitized.

The obtained results suggest that the invader seems to benefit from establishing the new trophic association with the native lime (bearing in mind the current outbreaking density and a high survival rate of the pest) and releasing from its domestic enemies. The low mortality due to parasitoids that are native to Siberia indicates that, at present, the local complex of parasitoid wasps is not effective to control the population on the alien moth in the invaded region in Western Siberia.

Institutional Review Board Statement: Not applicable.

Informed Consent Statement: Not applicable.

Data Availability Statement: The data presented in this study are available in Supplementary Material.

Funding: This research was funded by the Russian Foundation for Basic Research (No. 19-04-01029 A).

Acknowledgments: We thank Dr. Maria Tomoshevich (Central Siberian botanical garden (CSBG) SB RAS, Novosibirsk) for her help and hospitality during our stay in Novosibirsk. In the study, the materials of the bioresource scientific collection of the CSBG SB RAS “Collections of living plants indoors and outdoors" USU_440534 (Novosibirsk, Russia) were used.

\section{References}

1. Šefrová, H. Phyllonorycter issikii (Kumata, 1963) bionomics, ecological impact and spread in Europe (Lepidoptera, Gracillariidae). Acta Univ. Agric. Silvicult. Mendel. Brunen. 2002, 50, 99-104.

2. Kirichenko, N., Triberti, P., Ohshima, I., Haran, J., Byun, B.-K., Li, H., Augustin, S.., Roques, A., Lopez-Vaamonde, C. From east to west across the Palearctic: Phylogeography of the invasive lime leaf miner Phyllonorycter issikii (Lepidoptera: Gracillariidae) and discovery of a putative new cryptic species in East Asia. PLOS ONE 2017, 12(2): e0171104. doi:10.1371/journal.pone.0171104

3. Bednova, O.V., Belov, D.A. The lime leaf miner (Lepidoptera, Gracillariidae) in green spaces of Moscow and Moscow region. Bull. Moscow State Forest Univ. [Forestry Bull.] 1999, 2, 172-177. (in Russian)

4. Gninenko, Yu.I., Kozlova, E.I. The lime leaf miner in Russia and problems of biological control. Abstracts of the international conference of The International Organization for Biocontrol (IOBC) / Asia and Pacific Regional Section. Poland, Poznan, May 15-19, 2006, 16. (in Russian)

5. Kirichenko, N. The lime leafminer Phyllonorycter issikii in Western Siberia: some ecological characteristics of the population of the recent invader. Contemporary Problems Ecol. 2004, 7(1), 114-121. DOI:10.1134/S1995425514010077

6. Kirichenko, N.I., Triberti, P., Akulov, E.N., Ponomarenko, M.G., Lopez-Vaamonde, C. Novel data on the taxonomic diversity, distribution and host plants of leafmining moths of the family Gracillariidae (Lepidoptera) in Siberia based on the DNA-barcoding. Entomol. Rev. 2019, 90(6), 769-819. DOI: 10.1134/S0013873819060083

7. Ermolaev, I.V., Sidorova, O.V. Patterns of damage to Tilia cordata by Phyllonorycter issikii (Lepidoptera, Gracillariidae) in Izhevsk City. Entomol. Rev. 2012, 92, 403-408. 